\title{
O FORMALISTA EXPIATÓRIO: LEITURAS IMPURAS DE KELSEN NO BRASIL*
}

\author{
Fernando Leal
}

\section{RESUMO}

Neste artigo, ARgumento que a CARACterizaC̦Ão DE KELSEN COMO UM AUTOR FORMALISTA E POSITIVISTA (COMUM EM CONTEXTOS DE RECEPÇÃO DA SUA OBRA, COMO O BRASIL) SÓ PODE SER CONSIDERADA PLAUSÍVEL DEPENDENDO DO SENTIDO EM QUE AS EXPRESSÕES "FORMALISMO" E "POSITIVISMO" SÃO empregadas. Por um lado, MOSTRO POR QUE Kelsen não ERA UM FORMALISTA METODOLÓGICO (I.E., QUE CARACTERIZAVA O RACIOCÍNIO JURÍDICO COMO DEDUTIVO) E POR QUE A ASSOCIAÇÃO ENTRE POSITIVISMO JURÍDICO E ESSE TIPO DE FORMALISMO É PRoblemática. Por outro, defendo que o que Stanley Paulson CHAMA DE CRÍTICA DE FORMALISMO COMO ESVAZIAMENTO - JÁ DIRIGIDA CONTRA KELSEN NA ALEMANHA NO INÍCIO DO SÉCULO XX - DEVE SER LEVADO A SÉRIO EM SEUS PRÓPRIOS TERMOS, OU SEJA, COMO UMA PERSPECTIVA METODOLÓGICA QUE TAMBÉM PODE SER VALIOSA PARA INVESTIGAR A NATUREZA DO DIREITO. COM O AUXÍlIO DESSAS ANÁLISES, É POSSÍVEL DESFAZER A CARICATURA QUE AINDA INSPIRA CERTAS VISÕES DA OBRA DE KELSEN NO BRASIL.

\section{PALAVRAS-CHAVE}

KELSEN; FORMALISMO; POSITIVISMO JURÍDICO; DEDUTIVISMO; DESCRITIVISMO.

\begin{abstract}
THE CHARACTERIZATION OF KELSEN AS FORMALIST OR LEGAL POSITIVIST IS VERY COMMON IN CONTEXTS OF RECEPTION OF HIS WORK, SUCH AS BRAZIL. IN THIS PAPER, I ARGUE THAT WHETHER OR NOT SUCH DEPICTION CAN BE CONSIDERED ACCEPTABLE DEPENDS ON THE SENSE IN WHICH THE TERMS "FORMALISM" AND "LEGAL POSITIVISM" ARE USED. ON THE ONE HAND, I HOPE TO SHOW WHY KELSEN WAS NOT A METHODOLOGICAL FORMALIST (I.E., SOMEONE WHO CONCEIVES LEGAL REASONING AS DEDUCTIVE REASONING) AND WHY THE LINKING BETWEEN LEGAL POSITIVISM AND THIS KIND OF FORMALISM IS PROBLEMATIC. ON THE OTHER HAND, I CLAIM THAT WHAT STANLEY PAULSON CALLS THE CHARGE OF FORMALISM QUA EMPTINESS - WHICH HAD ALREADY BEEN ADDRESSED AT KELSEN IN GERMANY IN THE BEGINNING OF THE XX' ${ }^{T H}$ CENTURY - SHOULD BE TAKEN SERIOUSLY IN ITS OWN TERMS, I.E., AS A METHODOLOGICAL APPROACH WHICH CAN ALSO BE FRUITFUL TO INVESTIGATE THE NATURE OF LAW. WITH THE HELP OF THESE ANALYSES, IT IS POSSIBLE TO DISPEL THE CARICATURE THAT STILL INSPIRES SOME VIEWS OF KELSEN'S WORK IN BRAZIL.
\end{abstract}

\section{KEYWORDS}

KELSEN; FORMALISM; LEGAL POSITIVISM; DEDUCTIVISM; DESCRIPTIVISM.

\section{INTRODUÇÃO}

Parece claro que uma análise sobre a influência do pensamento de um autor em um determinado contexto pressupõe que os seus efeitos sejam apresentados e valorados à luz de certos acordos prévios a respeito do que signifique "o pensamento" dele. Sem que exista pelo menos um núcleo consensual a respeito das ideias que o autor 
sob consideração efetivamente defende ou sobre as interpretações plausíveis de sua obra - no sentido de serem coerentes com o conjunto dos seus pressupostos mais fundamentais -, não é possível, sobretudo, analisar se uma influência especificamente observável do seu "pensamento" em um determinado ambiente pode ser, de fato, considerada uma assimilação minimamente fiel da sua teoria. E, sem esses acordos, torna-se impossível diferenciar uma influência fidedigna de uma compreensão efetivamente errada da teoria $^{1}$ ou de uma simples adaptação enviesada de algumas das suas teses.

É certo que mesmo uma assimilação “com sinal trocado”, uma releitura "tergiversada” - para usar uma expressão de López Medina (2004, p. 31 ss.) -, ou alguma outra forma de compreensão parcial de uma teoria, seja ela originada por uma leitura seletivamente justificada para servir a determinados interesses no contexto de recepção, ${ }^{2}$ seja ela fruto de um acesso limitado ao "pensamento" do autor (porque, por exemplo, nem toda a sua obra foi traduzida para o idioma do local de recepção ou porque o debate desenvolvido no local de produção do pensamento é desconhecido no local de recepção), podem também ser vistas como uma influência. Nesses casos, porém, o senso comum que se estabelece a respeito de determinado pensamento não é uma consequência da influência direta do edifício teórico do autor, mas sim de uma leitura específica deste, que pode até ser completamente incompatível com a doutrina de referência. Sem embargo, o que se enfatiza neste momento não é a suposta necessidade de análises sobre as diferentes formas por meio das quais um pensamento produzido em um determinado lugar pode influenciar a teoria e a prática em contextos diferentes, mas apenas a importância de se investigar também se uma determinada visão amplamente compartilhada sobre o pensamento de um autor pode ser considerada uma expressão adequada ou não da sua obra. Isso é decisivo não apenas para o desenvolvimento de reflexões sobre as razões que levam a uma compreensão enviesada (ou "impura") de certa teoria estrangeira em um ambiente específico, mas também para a análise dos seus méritos e deméritos efetivos nesse contexto.

Embora quase óbvias, essas observações preliminares são importantes para reforçar a visão de que o modo como operadores do direito, estudantes e mesmo alguns teóricos compreendem o pensamento de determinado autor em certo ambiente (i.e., a [pseudo]influência desse autor naquele espaço) nem sempre exprime uma leitura compatível com os seus pressupostos. Nesse contexto, uma espécie de senso comum entre parcela não desprezível dos membros daqueles grupos que pode ser identificado ainda hoje no Brasil - e, provavelmente, também nos demais países da América Latina e em outros contextos de recepção das obras de Kelsen, embora, reconheço, faltem-me evidências empíricas para comprová-lo - sobre um suposto caráter formalista, tanto do projeto jusfilosófico kelseniano como da compreensão do processo de decisão jurídica a ele relacionado, revela um caso clássico de recepção no mínimo criticável de uma teoria desenvolvida em outro ambiente. 
A presença de uma compreensão inadequada de Kelsen entre nós é percebida, por exemplo, em um consciente mea culpa realizado por Eros Grau:

[f]ui um crítico exacerbado de Kelsen, ousadamente, até o momento em que verifiquei que há dois Kelsen: o verdadeiro, crítico formal do direito, e aquele em que o transformam alguns dos seus leitores. Percebi, então, que minhas críticas a Kelsen deveriam ser não a ele destinadas, porém a alguns supostos kelsenianos, aqueles que fazem com que a teoria de Kelsen seja importante não pelo que estuda, mas sim pelo que deixa de estudar. (GRAU, 2011, p. 33)

No mesmo sentido - e com afirmações mais fortes - afirma Dallari:

[...] é tão profunda a influência da obra de Kelsen no Brasil e em toda a América Latina, que vale a pena fazer algumas considerações sobre sua contribuição ao direito, sobretudo porque, com muita frequência, o que se utiliza é uma versão panfletária de seu pensamento, havendo muitos que se afirmam "'Kelsenianos”" sem nunca terem lido um só de seus livros ou, então, utilizando a versão difundida por juristas que encontraram, em parte da obra do eminente teórico, um bom escudo para a sustentação de posições formalistas antidemocráticas e contrárias à ética e à justiça. (DALLARI.

2002, p. 84)

No caso de Kelsen, além das confusões, a associação das suas teorias sobre o Direito e o Estado com epítetos como formalista ou positivista é acompanhada no Brasil quase sempre de certo tom pejorativo ou mesmo execratório. De fato, a evocação desses rótulos geralmente pretende sintetizar em fórmulas simples e com pretensões de suficiência justificadora um grupo de motivos pelos quais as supostas teses do autor (e todas as demais que possam ser reconduzidas a essas etiquetas) devem ser rejeitadas. Nesse cenário, existe não apenas um problema relacionado a uma leitura pouco fiel da obra de Kelsen, mas também outros problemas relacionados a uma caracterização imprecisa ou caricata do que seja formalismo ou positivismo jurídico. ${ }^{3}$

Somados, esses fatores formam, em alguns momentos, um quadro completamente grotesco - para nos servirmos de um adjetivo expressamente usado por Erich Kaufmann (1921, p. 29) para criticar um suposto logicismo do edifício teórico kelseniano - do projeto jusfilosófico subjacente à Teoria Pura do Direito (doravante TPD) e da concepção de Kelsen sobre o raciocínio judicial em casos de indeterminação do direito, que, exatamente por esse caráter extremado, quase absurdo, é capaz de ser facilmente demolido pelos críticos. ${ }^{4}$ Como se percebe pela referência a Kaufmann, a objeção formalista ao pensamento kelseniano não é, porém, um fenômeno típico de uma recepção 
transformadora da obra de Kelsen no Brasil ou na América Latina. Ao contrário, ela pode ser encontrada, como veremos, em obras de importantes publicistas alemães na primeira metade do século XX. O suposto caráter formalista do kelsenianismo não é, assim, um problema novo, embora, aparentemente, não completamente resolvido entre nós.

Tomando, então, por base, de um lado, a persistência de certa miopia sobre alguns pontos centrais do projeto kelseniano e, de outro, o sentido mais ordinário das expressões "formalismo" e "positivismo jurídico" no Brasil, este trabalho tem por principal escopo desfazer as relações supostamente existentes entre percepções imprecisas do pensamento de Kelsen por alguns membros da comunidade jurídica e elementos da própria obra do autor.

De forma mais específica, pretende-se mostrar (i) que uma simples leitura da TPD, a principal obra kelseniana recepcionada e, por isso, a referência fundamental das análises do presente trabalho, não dá qualquer espaço para associar a teoria da interpretação de Kelsen com "formalismo", entendido como método de justificação de decisões judiciais que parte da dedução de conclusões de normas ou conceitos gerais; e (ii) que a compreensão do projeto metodológico proposto por ele para se analisar o direito como "formalista" no sentido de "carente de substância" não leva, ainda que plausível, à caracterização anterior do raciocínio judicial e tampouco elimina a sua possível relevância para o desenvolvimento de investigações sobre a natureza do direito. Indiretamente, pretende-se, ainda, contribuir para o esclarecimento dos diferentes sentidos com que as expressões positivismo jurídico e formalismo são aplicadas. Assim, mais do que apresentar especificamente como algumas das ideias de Kelsen foram recebidas no Brasil e explicar como isso pode ter acontecido, este texto propõe, antes de tudo, uma investigação teórico-conceitual sobre as associações impuras existentes entre kelsenianismo e formalismo a partir do pressuposto de que a caracterização formalista ainda pode ser encontrada entre operadores do direito brasileiro quando as teses centrais sobre o projeto geral de filosofia do direito e a teoria da interpretação propostas na TPD são referenciadas. ${ }^{5}$

\section{O Kelsen fOrmalista}

A caracterização da TPD como uma obra de caráter formalista não é, como antecipado, somente um efeito de leituras transformadoras empreendidas na América Latina ou em qualquer outro contexto fora da Alemanha da primeira metade do século XX. ${ }^{6}$ Ao contrário, a objeção formalista foi frequentemente levantada contra Kelsen por importantes nomes do constitucionalismo de Weimar.

Em suas críticas, esses autores se referiam ao pensamento kelseniano como formalista essencialmente em dois sentidos inter-relacionados. Stanley Paulson (2008, p. 37) os sintetiza como formalismo qua dedução e formalismo qua esvaziamento. 
Determiná-los é fundamental para que se possa exprimir com exatidão o alvo das críticas formuladas contra o projeto kelseniano, tendo em vista a pluralidade de sentidos com os quais a expressão "formalismo" pode ser empregada. Com efeito, ela pode, por exemplo, designar tanto uma determinada postura judicial especificamente observável sobre o tratamento de problemas concretos ${ }^{7}$ como uma perspectiva sobre a estrutura do sistema jurídico, ${ }^{8}$ uma teoria normativa sobre a interpretação de textos normativos, ${ }^{9}$ uma atitude em relação ao uso de regras como razões para agir ou decidir (SCHAUER, 1988, p. 509-548) ou mesmo uma estratégia de decisão normativamente justificada sobre os seus efeitos empíricos positivos em um determinado arranjo institucional. ${ }^{10}$ Enquanto nos últimos dois casos o adjetivo "formalista" está associado a defesas autorais conscientes do formalismo, nos primeiros ela é geralmente apresentada por críticos com um tom desaprovador e quase sempre pejorativo para desqualificar algum projeto específico de teoria do direito ou as visões de terceiros sobre a decisão judicial ou sobre o raciocínio jurídico (SCHAUER, 1988, p. 509). ${ }^{11}$ Nesses últimos sentidos, a objeção formalista contra Kelsen é frequentemente levantada.

\section{I LOGICISMO E ESVAZIAMENTO}

As principais críticas a um suposto caráter formalista do pensamento kelseniano formuladas por autores alemães ${ }^{12}$ na primeira metade do século XX tinham por alvo primordial o próprio projeto metodológico de investigação do Direito e do Estado propostos por Kelsen na esteira do neokantianismo.

A caracterização da campanha do autor contra o naturalismo e o psicologismo por meio dos quais o direito era até então comumente compreendido como um logicismo pretendia salientar uma afirmada ausência de substância ou um esvaziamento conteudístico implicado pelos pressupostos sobre os quais a visão kelseniana de ciência do direito se sustentava. De fato, a pureza metodológica proposta por Kelsen tinha por principal pretensão a libertação dos processos de compreensão do direito dos elementos estranhos que tornaram a ciência do direito ao longo do século XIX e início do século XX, em sua visão, um amálgama de conhecimentos de outros domínios, como a psicologia, a biologia, a ética e a teologia (KELSEN, 1934, p. 1). Esse "esvaziamento" era, na verdade, necessário para que se pudesse falar em conhecimento puro, em sentido kantiano, de um determinado objeto (PAULSON, 2008, p. 37). Enquanto, por exemplo, o funcionalismo metodológico do segundo Jhering, no qual se inspiraram importantes obras jurídicas daquele período, enfatizava a importância de compreender o direito como fenômeno social a partir dos fins a que ele deveria servir; ${ }^{13}$ o projeto de Kelsen se direcionava aos meios por intermédio dos quais o direito se manifestava. Para Kelsen, “o direito é um meio, um meio social específico, não um fim” (1945, p. 20). ${ }^{14}$ Vincular a compreensão adequada do fenômeno jurídico a propósitos ou vontades era, na verdade, uma forma de manter a ciência do direito estruturalmente dependente do conhecimento de outros campos. 
Nesse quadro, a pureza metodológica proposta conduzia à limitação do objeto por excelência da ciência do direito aos meios por intermédio dos quais atos e fatos determinados são considerados direito, e não aos processos anímicos ou operações corporais que eventualmente justificariam por que o direito é necessário, posto ou obedecido. O único objeto do conhecimento do direito é, por isso, a norma, entendida não a partir de atividades psíquicas ou relações naturais, mas como categoria autônoma que não se deixa captar por referências aos planos natural ou psicológico (KELSEN, 1934, p. 6). Nas palavras de Kelsen, "[a] Teoria Pura do Direito - como ciência específica do direito - direciona sua atenção às normas jurídicas: não como fatos conscientes, não como o querer ou a representação das normas jurídicas, mas sim às normas jurídicas como conteúdos - desejados ou imaginados - de sentido” (1934, p. 10 s.).

A pureza como princípio metodológico fundamental (KELSEN, 1934, p. 1) do projeto kelseniano pretendia, assim, libertar a ciência do direito das explicações causais, do voluntarismo e também dos valores, porque isso era indispensável para que se pudesse conhecer adequadamente o seu objeto, i.e., o próprio direito. Compreender o fenômeno jurídico significava, nesse sentido, também desvinculá-lo de qualquer relação necessária com a moral ou de uma pretensão essencial de promoção da justiça, cujo conteúdo era considerado por Kelsen de forma alguma racional ou cientificamente apreensível (KELSEN, 1934, p. 13 s.). A justiça, para ele, não passava de um ideal irracional (KELSEN, 1934, p. 16).

Em vista de todos esses cortes metodológicos, a dissolução de noções como a de Estado e de sistema jurídico, da ideia de norma jurídica e outros elementos fundamentais de um projeto abrangente de compreensão do fenômeno jurídico em relações conceituais não era, em alguma medida, uma caracterização totalmente desprovida de sentido (PAULSON, 2008, p. 12, 38). O conceito de não direito (Unrecht) é, por exemplo, definido na TPD negativamente em função do que o direito determina (KELSEN, 1934, p. 27); a compreensão de Estado, sobre as mesmas bases, é construída a partir de um programa conceitual que parte da centralidade da caracterização kelseniana de proposição jurídica para a compreensão adequada do sistema das doutrinas do Direito e do Estado (KORB, 2010, p. 65) e de certas relações estabelecidas, como a que identifica Estado com direito (KELSEN, 1934, § 48; PAULSON, 2008, p. 12). O uso dessas ferramentas conceituais deve ser compreendido, no entanto, à luz do principal propósito do projeto kelseniano de estabelecer uma teoria geral do direito (KELSEN, 1934, p. 1). Como uma teoria do direito positivo de pretenso caráter geral - porque não se ocupa de nenhuma ordem jurídica específica -, a Teoria Pura desenvolve essas ferramentas para que um direito especial possa ser intelectualmente apreendido. ${ }^{15} \mathrm{O}$ objetivo buscado pela TPD é, sobretudo, apreender (begreifen) o direito posto sem valorá-lo, identificar o direito como ele é faticamente conformado, seja ele bom ou ruim, justo ou injusto (KELSEN, 1929, p. 1723). E é para alcançar esse objetivo que uma tipologia 
conceitual é desenvolvida e relações dentro dela são estabelecidas pelo autor. Nesse quadro, ambas se tornam demandas necessárias.

As possíveis implicações do postulado da pureza foram acentuadas e duramente criticadas. A atribuição do adjetivo "formalista” à opção metodológica kelseniana pretendia, antes de levá-la a sério como uma nova proposta para o empreendimento de investigações jusfilosóficas voltadas ao conhecimento do direito e, assim, diferenciá-la das demais visões dominantes à época a respeito (ainda que o rótulo escolhido fosse problemático), especialmente desqualificá-la.

Erich Kaufmann, em específico ataque aos pressupostos filosóficos epistêmicos neokantianos com base nos quais Kelsen desenvolveu suas doutrinas do Direito e do Estado, ${ }^{16}$ acusou-o de um logicismo radical e, ao caracterizar as bases do seu pensamento como "formalistas", de negligenciar os elementos políticos, psicológicos e sociológicos relacionados aos problemas da época, todos eles elementos que não se deixam logicamente "produzir" a partir de conceitos abstratos vazios (KAUFMANN, 1921, p. 28). ${ }^{17}$ Para Kaufmann, partir de categorias a priori - como a de "dever ser puro", considerado como sobreconceito do direito (Oberbegriff des Rechts) - era insuficiente para "purificar" conceitos empíricos (KAUFMANN, 1921, p. 21). ${ }^{18}$ Esse tipo de tentativa levaria, na verdade, apenas a um procedimento abstrativo a partir do qual elementos materiais seriam eliminados de conceitos empíricos até o ponto em que se chegaria a um conceito geral vazio, um conceito originário (Ursprungsbegriff), com base no qual outros seriam deduzidos (KAUFMANN, 1921, p. 21). Em sua crítica ao esvaziamento implicado pela tentativa de fundamentar certas teses sobre construções conceituais, assenta Kaufmann: "se se encara a realidade sob um determinado ponto de vista abstrato e se prescinde de todos os outros como 'desimportantes', salientase, então, reiteradamente apenas esse ponto de vista. Isso é tão evidente que, de fato, não é necessário de forma alguma ler os volumosos livros de Kelsen, que ludibriam por incontáveis exemplos sempre o mesmo pretenso artifício (Kunststück)" (1921, p. 21). O projeto lógico-normativo de Kelsen conduzia, na verdade, apenas a tautologias e a uma progressiva desmaterialização do direito, a qual, para Kaufmann, atingia o seu ponto culminante na ideia de Grundnorm (KORB, 2010, p. 116).

Hermann Heller (1992, p. 8) também destacou em tom crítico o caráter formalista ou positivista-logicista do programa metodológico de Kelsen para a construção de sua teoria sobre o direito público. A ascensão do positivismo representava, na verdade, a fonte de uma crise da teoria do Estado, isolada gradativamente da sociologia e, assim, separada da ética e da metafísica. Para ele, “o medo do positivismo jurídico da sociologia, da metafísica e da ética, sua aspiração simplista a um suposto formalismo isento de fatos e valores condenou-o [...] à completa impotência (Hilflosigkeit) em face de todos os verdadeiros problemas da teoria geral do Estado" (HELLER, 1992, p. 9). Excluídos o discurso dos fins estatais, as considerações sobre as necessidades humanas e quaisquer pontos de vista valorativos da análise dos conceitos de Estado e 
de direito, o que sobraria? Dada a insuficiência do método lógico-formal proposto pelo positivismo jurídico para dar conta das questões da teoria do Estado, se ele alcançasse realmente a primazia, uma tal teoria seria, na verdade, impossível. O ponto crítico emergiria dos problemas relacionados ao desenvolvimento de uma teoria do Estado dentro dessa realidade por aqueles que não desistissem da abordagem tradicional e reconhecessem a insuficiência do formalismo. Nesse caso, formar-se-ia outro quadro indesejável, marcado por uma incontrolável e radicalmente prolífera metafísica e uma pseudo e cripto-sociologia com as mesmas características (HELLER, 1992, p. 10).

Como legado do positivismo lógico, a proposta metodológica de Kelsen de análise do Estado e do direito, anunciada tanto em sua Teoria Geral do Estado (Allgemeine Staatslehre) como na TPD, foi, naturalmente, duramente criticada. Para Heller (1992, p. 20), seu racionalismo “dessubstancializador" vis-à-vis a realidade histórico-empírica do Estado acaba, ao contrário do que deveria fazer uma teoria do Estado, diluindo-o em relações lógico-conceituais, porque, para Heller (1992, p. 22), a compreensão adequada do direito e do Estado não poderia prescindir de análises sociológicas e políticas, não seria possível conceituar a Teoria Geral do Estado como Teoria do Estado e a TPD como ciência do direito, mas como lógica. Na crítica mais ácida direcionada contra Kelsen, caracteriza Heller em sua Staatslehre as bases positivistas kelsenianas, com as quais pretendia romper, como "uma teoria do direito sem direito, uma teoria do Estado sem Estado, uma ciência normativa sem normatividade e um positivismo sem positividade" (HELLER, 1983, p. 225).

Com o mesmo tom reprobatório, acentuou ainda Rudolf Smend (1928, p. 95) que, assim como Kaufmann, também escreveu seu trabalho de Habilitação sob a supervisão de Albert Hänels em Kiel e com ele aprendeu "que, em oposição ao positivismo clássico, era possível incorporar política, direito comparado ou história do direito no direito do Estado sem destruir as suas barreiras" (KORB, 2010, p. 123) - o potencial do racionalismo da teoria do Estado kelseniana para dissolver a realidade intelectual em ficção, ilusão, dissimulação e engano.

Como se percebe, em todos esses casos, adjetivos como "formalista" ou "logicista" eram empregados para destacar e, ao mesmo tempo, condenar um projeto teórico que não objetivava investigar e compreender determinadas ideias intimamente relacionadas aos conceitos de direito e/ou de Estado a partir de considerações históricas ou sociológicas ou análises substantivas de caráter político ou moral. Atribuir às doutrinas kelsenianas sobre o Direito e o Estado rótulos como "formalismo radical", "logicismo" ou simplesmente "positivismo", todos em alguma medida com sentidos convergentes no contexto das críticas, era uma maneira de extremar as suas diferenças e eventuais limitações vis-à-vis outras propostas metodológicas e, assim, também repudiá-las em poucas palavras.

Segundo o pressuposto levantado neste trabalho, nota-se ainda hoje uma tendência a caracterizar o "pensamento" kelsenianismo com os mesmos rótulos e com os mesmos 
tons ácidos em alguns contextos de recepção, mas sem necessariamente o mesmo tipo de embasamento teórico que pretendia, nos debates de Weimar, justificar o seu repúdio. No caso específico das objeções, a um alegado vazio de conteúdo das teorias de Kelsen sobre o Estado e o direito, em vez de se reforçarem as críticas por seus supostos méritos, herda-se apenas a síntese pejorativa expressada nos referidos rótulos conceitualmente problemáticos porque vagos e plurívocos -, que são repetidos quase sempre desacompanhados de fundamentos consistentes. São comuns, por exemplo, tentativas de expandir as razões de repúdio às teses da jurisprudência dos conceitos à TPD, como se houvesse um continuum ou uma semelhança de família evidente entre ambas. Para o próprio Kelsen, ao contrário, "querer diminuir a Teoria Pura como 'Jurisprudência dos Conceitos' - o que não acontece raramente - é [cometer] um malentendido verdadeiramente deplorável” (KELSEN, 1929, p. 1723).

\section{I.2 UMA COMPREENSÃO DEDUTIVISTA DO RACIOCÍNIO JURÍDICO}

Os problemas de um afirmado caráter formalista das teorias kelsenianas não se esgotam, entretanto, na caracterização do formalismo como esvaziamento. Longe disso, a verdadeira caricatura vinculada à atribuição do rótulo "formalista" à teoria do direito kelseniana se deixa notar na compreensão da sua teoria sobre a interpretação do direito como uma teoria dedutivista do raciocínio jurídico. Essa é provavelmente a visão mais comum entre operadores do direito no Brasil e em outros ambientes de recepção que absorvem e replicam uma compreensão impura das doutrinas de Kelsen.

A caracterização do formalismo qua dedução se aproxima da visão mais comumente relacionada à expressão "formalismo" no âmbito da teoria do direito. O adjetivo formalista é usado nesse contexto para distinguir concepções sobre a atividade judicial ou sobre o raciocínio jurídico, sejam elas de caráter descritivo ou normativo, que preconizam que juízes tomam (ou devem tomar) decisões com base na aplicação lógica (e, assim, não criativa) de conceitos, definições, categorias ou proposições relacionadas a textos legislativos a problemas jurídicos concretos. O processo de aplicação do direito é, sob essa perspectiva, reduzido à extração de conclusões consideradas como consequências lógicas da invocação de alguns daqueles elementos.

O tom crítico-depreciativo com o qual a expressão é empregada para se referir a teorias dedutivistas sobre o raciocínio jurídico se segue de três problemas vinculados a uma compreensão alegadamente restrita e fantasiosa do exercício da função jurisdicional.

Em primeiro lugar, uma atitude formalista seria criticável por negligenciar aspectos importantes do problema concreto a ser solucionado, ao se preocupar apenas com a seleção dos fatos ou das questões conceituais consideradas relevantes para a aplicação mecânica de definições ou de textos legais. Juízes formalistas tenderiam, assim, simplesmente a não responder as questões centrais das disputas jurídicas a eles apresentadas (PAULSON, 2005, p. 33). 
Em segundo lugar, o adjetivo formalista é usado para atacar determinadas teorias sobre o raciocínio jurídico com o referido perfil porque elas, na visão dos críticos, claramente almejam ocultar, por meio de uma caracterização aparentemente neutra do processo decisório, as razões determinantes para a solução de problemas concretos e, assim, encobrir as situações em que a discricionariedade judicial é efetivamente exercida. ${ }^{19}$

Finalmente, o rótulo "formalismo jurídico" é aplicado para designar e repudiar as teorias que se assentam sobre um mecanicismo judicial porque elas pressupõem a capacidade de o sistema jurídico ser capaz de fornecer uma única resposta para cada problema jurídico concreto. ${ }^{20}$ A dedução de juízos normativos singulares de proposições jurídicas só é uma atividade realmente neutra (no sentido de não valorativa) se não é possível questionar-se qual é a premissa maior do silogismo prático usado para justificar a decisão. E isso só é possível se o direito vigente é capaz de oferecer de antemão soluções abstratas e unívocas para casos específicos.

A referida caracterização e todo o conjunto enunciado de problemas têm, em contextos de recepção como o brasileiro, geralmente em Kelsen o exemplo e o alvo por excelência. Esse tipo de associação é, no entanto, de fácil destruição porque não resiste ao próprio texto da TPD. Por esse motivo, a objeção de que a teoria da interpretação de Kelsen pressupõe que o tomador de decisão não exerce qualquer atividade criativa e, por isso, pode ser caracterizado como um autômato, que aplica mecanicamente normas jurídicas a casos particulares, não é encontrada (pelo menos entre nomes relevantes) no contexto em que ela foi desenvolvida, apresentada e discutida.

Ao contrário, o próprio Kelsen se serve de uma caracterização desse tipo para atacar o argumento de Carl Schmitt, no célebre debate sobre o guardião da Constituição, de que a necessidade de a jurisdição constitucional ser exercida pelo Presidente do Reich se seguiria da diferenciação conceitual que pode ser estabelecida entre os processos de aplicação da Constituição e de aplicação ordinária do direito (KELSEN, $1930 / 31$, p. 588 ss.). Para Schmitt, a atividade judicial seria essencialmente vinculada a normas; na verdade, a normas que possibilitam uma subsunção fática e cujos conteúdos não são duvidosos ou discutíveis. Não haveria nesses casos, por isso, qualquer espaço para interpretação, ${ }^{21}$ porque, por outro lado, as normas a serem aplicadas pela jurisdição constitucional seriam, do ponto de vista do conteúdo, frequentemente duvidosas ou questionáveis, ao contrário do que ocorre na solução de casos por juízes, a atividade do tribunal constitucional não deveria ser vista como a atividade de um órgão aplicador do direito (PAULSON, 2005, p. 46 s.).

Para Kelsen, a imagem de $\mathrm{Schmitt}^{22}$ de que "a decisão judicial já está prontamente contida na lei, [ou seja] apenas no sentido de uma operação lógica é dela derivada" é equiparável à concepção do Judiciário como autômato do direito (KELSEN, 1930/31, p. 591 ss.). Demonstrando que não endossa tal caracterização do raciocínio judicial, Kelsen critica expressamente esse reducionismo. Ao contrário do quadro pintado por 
Schmitt, juízes, por um lado, também lidam com problemas que envolvem a aplicação de normas cujas prescrições exatas são duvidosas ou questionáveis (KELSEN, 1930/31, p. 588). Tribunais diversos não decidem casos que envolvem apenas questões fáticas, mas também questões jurídicas; por outro lado, ainda segundo Kelsen, não é correta a afirmação de que decisões sobre a constitucionalidade de leis nunca exprimem uma subsunção de uma configuração fática (mas, sim, a determinação do conteúdo de uma disposição constitucional cujo conteúdo é duvidoso), se se considera que a Constituição regula não apenas o processo legislativo, mas também os conteúdos que futuras leis ordinárias não podem ter. Porque, para Kelsen, o "fato" a ser subsumido a uma disposição da Constituição no exercício da jurisdição constitucional não é a norma, mas o fato da sua aprovação, é possível também se falar em subsunção no controle de constitucionalidade de leis. O ponto de divergência aqui seria, sobretudo, a concepção obscura de Schmitt sobre o que ele entende por fato ou, mais precisamente, pela proposição fática relacionada ao âmbito de incidência de uma norma (Tatbestand) (KELSEN, 1930/31, p. 589; PAULSON, 2005, p. 47).

Além desses motivos, estaria a chamada "teoria do autômato" em expressa relação de tensão com a própria teoria decisionista schmittiana, que enfatiza a dimensão político-volitiva por trás de todas as expressões do direito. ${ }^{23}$ Se é certo que Schmitt reconhece em qualquer decisão, até mesmo nos processos decisórios de tribunais estruturados sobre a subsunção de fatos a normas, um elemento de pura decisão "que não pode ser deduzido do conteúdo da norma” (SCHMITT, 1931, p. 45 s.), conclui Kelsen que não pode existir qualquer diferença qualitativa entre legislação e decisão judicial (KELSEN, 1930/31, p. 592), exatamente o ponto de partida alegado por Schmitt para diferenciar o processo de aplicação do direito da jurisdição constitucional. Nesse sentido, sintetiza Paulson a afirmada inconsistência interna:

[a] alegação de que o exame judicial [de constitucionalidade] de uma lei, por conta de seu caráter político, não exprime uma aplicação do direito não se sustenta porque todas as formas jurídicas possuem caráter político. E isso deveria logo ser reconhecido pelo "decisionista" Schmitt [...]. Como pode Schmitt insistir que a aplicação do direito só se deixa explicar nos termos do modelo dedutivo da subsunção, se a sua própria teoria "decisionista" fala contra uma tal suposição? (PAULSON, 2005, p. 48)

Que Kelsen não concebe a tomada de decisão jurídica como um processo mecânico-dedutivo torna-se, não obstante as passagens sobre o assunto no âmbito do debate travado com Carl Schmitt, algo ainda mais claro quando a sua teoria da interpretação é analisada. De fato, Kelsen assevera que, como regra, a interpretação de uma lei é um procedimento intelectual que se ocupa com a resposta para a seguinte questão: “como a partir da norma legislativa geral, na sua aplicação concreta a um fato, extrai-se 
a correspondente norma individual de um julgamento judicial ou de um ato administrativo?” (KELSEN, 1934, p. 90).

A impressão, no entanto, de que Kelsen entende que a norma legislativa determina completamente o resultado de um juízo normativo singular na relação entre dois níveis diferentes (superior e inferior) da ordem escalonada (Stufenbau) do direito é insustentável não apenas porque ele o diz expressamente, ${ }^{24}$ como também porque ela é absolutamente incompatível com o reconhecimento de uma inafastável dimensão volitiva nos processos interpretativos. O processo jurídico-cognitivo subjacente à atividade interpretativa é, para Kelsen, no máximo capaz de fornecer um conjunto possível de soluções para um determinado caso, mas não uma única solução, como se cada norma fosse capaz de determinar um resultado para qualquer tipo de problema concreto. Cognição jurídica significa apenas redução das alternativas de decisão. O resultado do procedimento interpretativo, como expressão dessa cognição, fixa, assim, apenas uma moldura que delimita os resultados juridicamente possíveis relacionados à norma aplicável (KELSEN, 1934, p. 94 s.).

A escolha por uma dessas opções é considerada um ato de vontade do tomador de decisão, não de conhecimento do direito. Determinar qual das opções dentro da moldura pode ser considerada “correta” é, para Kelsen, um problema não relacionado ao conhecimento do direito positivo e, dessa forma, não é uma questão de teoria do direito, mas um problema jurídico-político (KELSEN, 1934, p. 98). Com isso, Kelsen se afasta completamente do que ele mesmo chama de "teoria do direito tradicional" (traditionelle Jurisprudenz), que acredita no potencial da atividade interpretativa e dos cânones nos quais ela se orienta de conduzirem o tomador de decisão a respostas únicas e corretas, como se o processo cognitivo fosse capaz de sufocar qualquer atividade volitiva do intérprete em processos de aplicação do direito. Aplicação e criação são, para Kelsen, tarefas que andam juntas em qualquer processo interpretativo, ainda que seja correto que a atividade de cognição do direito limite a margem criativa do intérprete (PAULSON, 2008, p. 23).

Kelsen é, por isso, cético em relação à utilidade de métodos tradicionais de interpretação e ao valor de uma máxima (Grundsatz) da ponderação de interesses. Além disso, não reconhece lacunas genuínas no direito. Mais uma vez, essas são conclusões que não se seguem de uma compreensão formalista da atividade judicial amparada na crença de que cada nível da estrutura escalonada da ordem jurídica vincula exaustivamente a "produção" de normas no plano inferior.

O ceticismo em relação aos métodos de interpretação decorre da impossibilidade de eles levarem a um único resultado correto. Eles conduzem o tomador de decisão apenas a resultados possíveis. Para Kelsen, do ponto de vista do direito positivo, é completamente indiferente se alguém negligencia o texto e se orienta na presumida vontade do legislador ou observa estritamente o texto a fim de não se preocupar com a vontade do legislador (KELSEN, 1934, p. 96). Da mesma forma, recorrer à analogia 
ou ao argumentum a contrario é completamente desnecessário, porque eles podem conduzir a resultados opostos e não há qualquer critério que determine quando um ou outro deve ser usado (KELSEN, 1934, p. 97). No mesmo sentido, também a máxima da ponderação de interesses não oferece qualquer medida para se comparar os interesses e, assim, decidir o conflito entre eles (KELSEN, 1934, p. 97). Servir-se desses métodos na tentativa de fundamentar a eventual correção de uma decisão é, por esses motivos, apenas uma maneira de tentar dissimular o aspecto volitivo (ou político) da decisão. Eles são, ao contrário do que se supõe, simples mecanismos que efetivam opções políticas e visões ideológicas. Finalmente, o argumento para a inexistência de lacunas genuínas no direito é uma consequência do reconhecimento da dimensão volitiva por trás de qualquer processo de criação e interpretação do direito. Se o direito não obriga determinada conduta, é porque ela é permitida (KELSEN, 1934, p. 100 s.); se o direito não reconhece um direito, é porque ele simplesmente não existe (PAULSON, 2008, p. 21). Uma "lacuna” estaria, assim, não relacionada à inexistência de uma norma, mas à alegação de que o modo como determinado caso foi regulado é injusto ou funcionalmente inapropriado. Nesse caso, "lacuna" não é nada mais do que a diferença entre o direito positivo e uma ordem considerada como melhor, mais justa ou mais correta (KELSEN, 1934, p. 101).

Como se percebe, ao contrário de conceber o processo jurídico de tomada de decisões judiciais como um processo mecânico de dedução de conclusões a partir de normas "superiores", Kelsen procura permanentemente se afastar desse tipo de formalismo e dos mitos que o informam. A Teoria Pura renega expressamente tanto a tese da jurisprudência dos conceitos, de que a interpretação é uma atividade puramente de conhecimento do direito positivo, como a ilusão de plena segurança jurídica que a teoria do direito tradicional pretende, consciente ou inconscientemente, manter (KELSEN, 1934, § 39). Para surpresa e estranhamento dos críticos, Kelsen já endossou expressamente a alegação de que, no campo da interpretação jurídica, a sua Teoria Pura e o Movimento do Direito Livre (Freirechtsbewegung), um exemplo óbvio de repúdio ao formalismo, estão em um terreno comum (PAULSON, 2008, p. 20).

Se à luz desses elementos é, então, evidente que a associação entre a visão de Kelsen sobre o raciocínio judicial e um formalismo mecanicista é plenamente sem sentido, como ela se explica? Parece-me que, no presente caso, há uma espécie de importação imprópria dos supostos problemas relacionados à crítica do esvaziamento, direcionada ao projeto metodológico sugerido por Kelsen para a compreensão adequada do direito para a teoria da interpretação.

O suposto "formalismo" relacionado à purificação da ciência do direito, à criação de uma nova gramática para explicar os elementos distintivos do direito e à compreensão de certas noções por meio de relações lógico-conceituais é transplantado para uma teoria do raciocínio jurídico que ergue uma pretensão de consistência com os pressupostos metodológicos da TPD, como se uma compreensão mecânico-dedutivista 
do raciocínio judicial fosse uma consequência presumível de uma teoria do direito que pretende libertar a ciência do direito (e não o direito) de elementos de outros domínios. Busca-se harmonizar dentro da teoria uma concepção sobre a tomada de decisão jurídica aparentemente "natural” à vista de seus pontos de partida e de alguns dos seus elementos: uma ciência do direito pura significa uma teoria da decisão judicial igualmente pura no sentido de sem conteúdo ou avalorativa; a centralidade do conceito de norma como o objeto por excelência do conhecimento do direito leva à redução do direito ao conjunto de normas positivadas e, assim, ao protagonismo das normas jurídicas como fontes determinantes e exaustivas de juízos normativos singulares; uma compreensão escalonada do ordenamento inspira uma concepção estruturada do processo de tomada de decisão jurídica em níveis hierarquizados, tal qual se pode entender as relações entre as premissas maior e menor de um silogismo prático.

Transições desse tipo são não apenas problemáticas, porque desnecessárias, como, no caso de Kelsen, também falsas, ${ }^{25}$ ao enunciarem conclusões expressamente em desacordo com o texto da TPD. Desenvolver uma "teoria do direito positivo" como propõe Kelsen, significa fundamentalmente entender que questões políticas, morais ou psicológicas não são objeto de uma verdadeira, ou "pura", ciência do direito, e não que elas não existam ou sejam desimportantes. Aspectos políticos, ideológicos e de outras naturezas influenciam, sim, a tomada de decisão jurídica, ainda que não digam respeito, para Kelsen, aos objetos de investigação de uma teoria do direito.

Essas transições de pressupostos efetivamente endossados por Kelsen para conclusões sem qualquer amparo textual ou interpretações inconsistentes com a própria TPD poderiam ser explicadas por meio da busca pela promoção de certos interesses locais nos ambientes de recepção, de dificuldades para o conhecimento profundo da obra do autor e das discussões em torno dela estabelecidas no ambiente de produção nos contextos periféricos (LÓPEZ MEDINA, 2004) ou mesmo de leituras parciais de textos canônicos feitas por receptores acadêmicos ou operadores do direito. Tentar justificar neste momento qualquer uma dessas hipóteses como válida para o caso brasileiro extrapolaria, no entanto, os limites deste trabalho.

\section{O Kelsen positivista}

Se é fato que o adjetivo "formalista" já era empregado na Alemanha para designar teses kelsenianas com um tom crítico-depreciativo, é possível, ao menos em alguma medida, problematizar a hipótese de que a abertura do contexto hermenêutico nos locais de recepção por meio da ampla divulgação dos debates travados em torno da obra estrangeira recepcionada poderia facilitar a identificação de erros ou interpretações inadequadas. Com outras palavras, porque a leitura formalista de Kelsen também era comum no próprio ambiente de produção da TPD, é questionável se o acesso aos debates alemães por teóricos latino-americanos durante o período em que a obra, 
em um primeiro momento, foi recebida e divulgada nos círculos acadêmicos locais e, em um segundo momento, inspirou a criação de um senso comum (ou "pop”, como caracteriza López Medina) desviante, que tentava amoldá-lo sincreticamente ${ }^{26}$ com o formalismo clássico da jurisprudência dos conceitos, ${ }^{27}$ poderia efetivamente esclarecer a insustentabilidade da crítica dedutivista. Ao contrário, nada impediria que o acesso a tais debates pudesse até contribuir para reforçá-la, desde que estes também passassem por um processo de transformação.

O caso específico de Kelsen, naturalmente, não invalida a hipótese geral de que algumas limitações do contexto hermenêutico de recepção de uma obra ou "pensamento" produzido em outro contexto podem contribuir para uma compreensão desviante das ideias centrais do(s) autor(es) de referência. O exemplo kelseniano reforça, entretanto, algo singelo: a melhor forma de se compreender uma teoria é analisá-la em seus próprios termos. ${ }^{28}$ Como expressão de um compromisso com a manutenção da integridade da obra de um autor, essa fórmula estabelece parâmetros de controle mínimos com base nos quais leituras claramente discrepantes podem ser denunciadas. Não só isso, ela também sugere que a teoria seja compreendida no universo mais amplo de propostas que compartilham dos seus pressupostos fundamentais. Isso, como vimos, é fundamental para o reconhecimento, por um lado, da impropriedade de uma compreensão lógico-dedutiva do raciocínio jurídico sustentada na TPD; e, por outro, a fórmula também é importante para um entendimento adequado do método kelseniano de investigação das propriedades distintivas do direito e, assim, para a determinação exata do ponto mais profundo da crítica formalista qua esvaziamento, a única que pode ser considerada realmente significativa. Entendê-la nos leva à caracterização da TPD como uma teoria positivista do direito.

Tal qual ocorre com o emprego do adjetivo "formalista", o rótulo "positivista" também ergue - especialmente quando proferido em círculos não acadêmicos - a pretensão de sintetizar em tom depreciativo um conjunto heterogêneo de críticas, muitas delas descabidas, direcionadas contra um autor ou uma teoria. Com Kelsen e a TPD não é diferente. Por esse motivo, a apresentação da TPD como uma teoria positivista do direito exige, antes de tudo, que se esclareça em que sentido, entre tantos possíveis, ela é de fato uma teoria positivista. O desenvolvimento dos debates em torno da identificação do núcleo duro do positivismo jurídico e o enfrentamento das objeções depreciativas decorrentes de mitificações das suas supostas teses centrais ocorridos especialmente depois da publicação da segunda edição da TPD (1960) serão usados como base para definir o que é o positivismo jurídico, a despeito do seu possível aspecto problemático para se referir ao modo como Kelsen foi inicialmente caracterizado como positivista em um sentido pejorativo. Ainda, como anunciado, que essa explicação fundamentada em obras recentes seja pouco útil para se entender por que a Kelsen foi atribuído o adjetivo "positivista” em um sentido inapropriado - algo que está fora dos objetivos do presente trabalho -, ela permanece, 
contudo, frutífera para problematizar por que a referida caracterização depreciativa ainda permanece.

A atribuição do rótulo "positivista" a Kelsen pretende condensar duas críticas: a primeira diz respeito a um suposto modo como Kelsen concebe o processo de aplicação do direito e a força vinculativa dos comandos normativos; e a segunda pretende atacar o próprio projeto metodológico proposto por Kelsen para se investigar o direito como fenômeno socioinstitucional. Como veremos, apenas a segunda crítica pode ser levada a sério, já que realmente considera a TPD em seus próprios termos.

No âmbito do primeiro conjunto de críticas, positivismo é usado como sinônimo de formalismo e legalismo. No que toca à caracterização formalista, o adjetivo positivista é aplicado para designar uma teoria do raciocínio jurídico que reduz a aplicação do direito à subsunção neutra de fatos ao predicado fático de prescrições legislativas. ${ }^{29}$ Como já esclarecido, essa tese é inválida quando evocada para descrever a visão de Kelsen sobre o tema. No segundo caso, o mesmo adjetivo é usado para caracterizar teorias jurídicas que sustentam a seguinte tese: as normas do direito merecem observância sob quaisquer circunstancias (HOERSTER, 1989, p. 10). Kelsen, da mesma forma, jamais defendeu uma tal concepção. Fazê-lo pressuporia vincular às normas positivadas, pela sua simples existência, um mérito moral que justificaria o dever cego de observância por autoridades e demais destinatários dos seus comandos.

Para uma teoria do direito positivo nos moldes kelsenianos, a existência e a análise desse suposto mérito são, porém, irrelevantes. Mas, como vimos, não porque à observância de regras não seja possível reconduzir qualquer valor, mas simplesmente porque, se esse mérito existe, ele não é objeto da ciência do direito. A tese do legalismo é, por isso, conceitualmente incompatível com o próprio postulado metodológico da pureza. Para dirimir qualquer dúvida, o próprio Kelsen expressamente admite que "a ordem moral não prescreve a obediência à ordem positiva do direito sob quaisquer circunstancias" (KELSEN, 1992 (1960), p. 70).

Tanto na versão formalista como na legalista, a crítica positivista pode, então, ser considerada inválida porque não se aplica a Kelsen. Mas não só isso, a inadequação da crítica decorre, no fundo, do que ela pressupõe serem teses capazes de definir conceitualmente o positivismo jurídico.

Em curtos meios, o que se pode chamar de núcleo duro do positivismo jurídico certamente aplicável à teoria do direito de Kelsen - é composto de duas teses: a tese da separação (“o que o direito é?” e “o que o direito deve ser?” são questões diferentes e independentes ${ }^{30}$ ) e a tese dos fatos sociais (o que pode ser considerado direito em qualquer sociedade depende fundamentalmente de fatos sociais ${ }^{31}$ ) (LEITER, 2001, p. 356). ${ }^{32}$ Nesse sentido, quaisquer outras teses (como a do formalismo ou a do legalismo) são, no máximo, contingentemente positivistas. Estranhamente, no entanto, é comum encontrar supostas versões do positivismo jurídico que efetivamente aceitem 
teses subsidiárias como as duas mais citadas nas páginas das obras dos seus opositores do que entre os seus defensores (HOERSTER, 1989, p. 8).

Como adiantado, a crítica "positivista" que realmente atinge algum alvo quando direcionada a Kelsen diz respeito à sua concepção sobre os objetos de preocupação da filosofia do direito e à perspectiva metodológica propugnada para desenvolver o projeto de investigação da natureza do direito proposto na TPD. Neste ponto, as críticas positivista e formalista qua esvaziamento convergem. O tom pejorativo com que Kelsen é chamado de formalista ou positivista pretende, em ambos os casos, essencialmente desqualificar o tipo de investigação filosófica proposto por ele para "descobrir a natureza do próprio direito, determinar a sua estrutura e as suas formas típicas, independentemente do conteúdo variável que ele exibe em diferentes períodos e entre diferentes pessoas" (KELSEN, 2006 (1941, p. 44-70), p. 154). O ponto sob discussão neste momento extrapola os debates tradicionais entre positivistas e não positivistas sobre o conteúdo dos critérios da validade e diz respeito à metodologia da filosofia do direito.

De uma forma geral, a dimensão metodológica dos debates sobre as diferentes teorias sobre a natureza do direito (entre as quais se localizam as teorias positivistas e não positivistas em suas diferentes versões) concentra-se nas disputas entre perspectivas descritivistas e normativistas. ${ }^{33}$ Projetos teóricos como os de Kelsen e Hart são descritivistas porque visam entender o direito tal qual ele se manifesta e sem valorar o seu conteúdo. Isso não impede que projetos dessa natureza possam conceber o direito como um sistema normativo. Para descritivistas, tampouco é problemática qualquer tarefa de descrever a normatividade do direito ou de analisar um conceito substantivo como o de direito sem emitir juízos de valor sobre o seu conteúdo. As proposições teóricas sobre o que as normas jurídicas prescrevem são asserções que apenas descrevem o “dever ser” relacionado a elas (KELSEN, 2006 (1941, p. 44-70), p. 159). ${ }^{34}$ Já os normativistas concebem a filosofia do direito como um projeto de filosofia política ou de qualquer outra natureza que se posiciona sobre as questões controversas que envolvem o fenômeno jurídico. ${ }^{35}$ Para eles, não é possível desenvolver uma teoria do direito apropriada sem que se refira a propriedades materiais do direito (como as funções a que ele deve servir ou a noção de autoridade) ou se questione o valor substantivo de se viver sob o direito (COLEMAN, 2007, p. 599). A forma por excelência de se levar adiante um projeto desse tipo é tentar compreender o fenômeno jurídico em suas melhores luzes a partir de funções ou propósitos aos quais ele deve necessariamente servir, como a promoção do bem-comum, o exercício justificado da coerção estatal ou a composição harmônica entre os ideais de justiça e segurança.

Nesse contexto, rotular uma teoria ou um autor de positivista é uma forma de menosprezar o projeto descritivista. ${ }^{36}$ Entender a natureza do direito, como já destacavam os críticos de um afirmado esvaziamento conteudístico provocado pelo postulado da pureza, requer compreendê-lo também a partir das suas dimensões relacionadas 
a outros campos, como a política, a sociologia ou a moral. A acusação dos críticos de formalismo como esvaziamento, destaca Paulson, reflete, no fundo, suas próprias inclinações, entre as quais se encontra uma concepção específica sobre como a filosofia do direito deve parecer (PAULSON, 2008, p. 39). Na medida em que o postulado da pureza afasta as dimensões política e moral do direito do projeto kelseniano de investigação da sua natureza, esses críticos se servem de etiquetas como positivismo e formalismo para descartar completamente o tipo de metodologia da filosofia do direito proposto, sem, porém, levá-lo a sério como mais um caminho possível, certamente com virtudes e problemas, para a realização de investigações sobre propriedades importantes do direito ou do Estado.

\section{CONCLUSÃo}

As análises anteriores procuraram diferenciar duas imagens de um Kelsen formalista e positivista: a que pode ser extraída fidedignamente da leitura dos seus textos e a que foi construída caricata e pejorativamente para não apenas criticar, mas, sobretudo, menosprezar as suas teorias sobre o direito, o Estado e a tomada de decisão judicial.

As objeções formalista e positivista, como apresentado, acompanharam frequentemente Kelsen, embora tenham sido formuladas em sentidos diversos. Na maior parte das críticas acadêmicas desenvolvidas no contexto de produção, a atribuição desses rótulos tentava manter sempre algum mínimo ponto de contato com a própria obra, ainda que em alguns casos sustentassem proposições não necessariamente compatíveis com as teorias atacadas. Nos contextos de recepção, contudo, prevaleceu - e ainda prevalece - no imaginário de parte relevante de operadores do direito e juristas não familiarizados com temas jusfilosóficos sentidos completamente esdrúxulos dessas expressões e, com isso, uma visão caricata de Kelsen, considerado o maior expoente e fonte das caracterizações locais do que seja formalismo e positivismo jurídico.

O pressuposto assumido neste trabalho é o de que no Brasil essa percepção do "pensamento" de Kelsen permanece até hoje inalterada. Ela perdura como uma espécie de patologia, um "kelsenismo" - Dallari (2002, p. 84) também emprega a expressão nesse sentido. Embora não se deva negligenciar a importância de investigações destinadas a explicar como se deu essa transição entre a recepção e a divulgação por círculos acadêmicos locais tanto dos textos de Kelsen como das críticas contra ele formuladas até a formação do senso comum que vincula a Kelsen teses indefensáveis, procurou-se nesta análise apenas fornecer subsídios conceituais para desfazer compreensões e associações impuras sobre as relações entre teses kelsenianas, formalismo e positivismo. Fazê-lo é fundamental para que, mesmo nos momentos de crítica, o Kelsen transformado não substitua o verdadeiro Kelsen. 


\section{NOTAS}

* Gostaria de agradecer a Joaquim Falcão, Mário Brockmann Machado, Márcio Grandchamp e demais participantes do seminário de pesquisadores da FGV Direito Rio realizado no início de 2012, no qual apresentei a primeira versão deste trabalho, e, ainda, a Fábio Shecaira, Pedro Adamy, Caio Farah Rodriguez, Diego Werneck Arguelhes e Ivar Hartmann pelos valiosos comentários e sugestões a versões anteriores deste texto.

1 Uma compreensão deve se entender claramente errada quando é inconsistente (no sentido de logicamente incompatível) com a própria teoria. Isso ocorre quando a visão sobre o pensamento de determinado autor que se estabelece no local de recepção pode ser expressa em uma proposição A, enquanto o que a teoria efetivamente sustenta pode ser representado por A.

2 Sirvo-me das expressões "contexto/ambiente/local de produção" e de "recepção" também no sentido proposto por López Medina. Sobre isso, cf. López Medina (2004, p. 15 ss.).

3 Embora o presente estudo se concentre nas chamadas "associações impuras” entre o pensamento kelseniano e sentidos específicos das expressões "positivismo" e "formalismo", merecem destaque obras de autores brasileiros, algumas também com contribuições internacionais, sobre Kelsen que se voltam tanto à apresentação adequada das suas ideias como à diluição de mal-entendidos sobre pontos específicos da teoria e mesmo à indicação de possíveis inconsistências internas na obra do autor. É, por isso, até certo ponto irônico constatar a convivência entre textos densos e fiéis a Kelsen entre nós, de um lado, e a existência e, sobretudo, a permanência de leituras criticáveis do pensamento kelseniano, de outro. Sem qualquer pretensão de esgotar essa literatura não tergiversada sobre Kelsen entre nós, cf. Dias (2010); Reale (1985, p. 15-30); Rodriguez (2011, Mimeo, especialmente o capítulo 3.1); Oliveira e Trivisonno (2013); Schuartz (2005, p. 1-61); Sgarbi (2006, p. 808-813; 2007).

4 A caracterização mais grotesca certamente é a que pretende apresentar tanto o positivismo como o formalismo como concepções sobre o direito e o raciocínio judicial legitimadoras de regimes totalitários, notadamente o nacionalsocialismo alemão. Para o caso mais geral de associação entre positivismo e totalitarismo, v. Comparato (2006, cap. X), em que é possível encontrar passagens como: "[o] último argumento aqui transcrito da tese sustentada por Hans Kelsen, a respeito da separação entre moral e direito, é da maior importância, pois ele nos dá uma chave explicativa do peso histórico do positivismo jurídico, como elemento de legitimação, tanto da submissão da esfera política à econômica, na ordem capitalista, quanto da lógica de funcionamento do Estado totalitário" (p. 361); e "[...] é inegável que os positivistas do direito contribuíram, decisivamente, pra o surgimento, no século XX, de um dos piores monstros que a humanidade jamais conheceu em toda a sua longa história: o Estado totalitário” (p. 363). Sobre a rejeição explícita do formalismo pelos juízes alemães durante o nazismo, cf. Müller (1992, p. 80 s.).

5 São exemplos que assumem e ao mesmo tempo repercutem visões contestáveis a respeito de Kelsen e de seu projeto teórico passagens como (i) "[j]á no século XX, Hans Kelsen desenvolveu essa ideia de sistema fechado, afastando a intrusão de juízos de valor na análise jurídica do direito positivo. [...] Dentre as características fundamentais do sistema fechado previsto pelo positivismo jurídico, tem-se a rígida estrutura formal, com hierarquia entre as normas; a aproximação quase plena entre Direito e norma; a afirmação da estatalidade do Direito e o papel do juiz apenas o de executar a subsunção do fato concreto à norma jurídica" (SARAIVA, disponível em: < http://jus.com.br/revista/texto/21751/pospositivismo-ciencias-sociais-e-o-papel-do-magistrado\#ixzz2J1EP0KAZ>. Acesso em: 25 jan. 2013 - grifo acrescido) e "[j]á na Teoria Pura do Direito, Kelsen consolida o direito como um sistema extremamente legalista, caracterizado por um excesso de formalismo, no qual a tarefa do juiz se restringe apenas à aplicação de um fato a uma norma, livre de qualquer ideologia" (EBAID, disponível em: <http://intertemas.unitoledo.br/revista/index.php/ETIC/article/viewFile/1622/ 1545>, p. 2. Acesso em: 25 jan. 2013).

6 Stanley Paulson, no último caso, mostra como a leitura formalista das obras de Kelsen também ecoou nos EUA. Roscoe Pound caracteriza, por exemplo, a teoria do direito kelseniana como um "logicismo normativo". Com suas palavras "[a]ppealing to formal logic, he [Kelsen] tries to find conceptions from which pure norms can be derived". Essa visão, como veremos, não se sustenta quando uma leitura atenta da TPD é levada adiante. Sobre o assunto, cf. Pound (1933-4, p. 532) e Paulson (2008, p. 15 s.).

7 Nesse sentido, é comumente caracterizada a Suprema Corte dos EUA durante a chamada Era Lochner. Cf. Tamanaha (2006, p. 47 ss.) e Summers (1983, p. 20). 
8 O adjetivo formalista é empregado nesse caso para designar uma compreensão do sistema jurídico que o define como completo, fechado e consistente.

9 Nessa perspectiva, textos normativos devem ser interpretados de modo a privilegiar sempre (e exclusivamente) o sentido literal das palavras que os compõem.

10 Neste caso, a referência é o "novo formalismo" desenvolvido na Faculdade de Direito de Chicago no final do século XX, que engloba nomes como Richard Epstein, Cass Sunstein e especialmente Adrian Vermeule. Sobre o tema, cf. Sunstein (1999, p. 636-670) e Vermeule (2006). Thomas Grey (disponível em: <http://ssrn.com/abstract=200732>. Acesso em: 10 jan. 2011), por sua vez, toma Antonin Scalia como referência do que conceitua como novo formalismo.

11 Exemplos do uso deliberado da expressão em tom crítico-depreciativo podem ser encontrados claramente durante o surgimento e a ascensão do pragmatismo jurídico e do realismo jurídico nos EUA, quando ambas as perspectivas se apresentavam como alternativas opostas a uma caricatura da atividade jurisdicional definida como "formalista". Nessa caracterização, a práxis judicial é compreendida como permanentemente orientada na extração de soluções unívocas para casos concretos a partir da simples dedução de conceitos amplos ou textos legislativos, entendidos como premissas de um silogismo prático. Em vista das claras insuficiências de tal caracterização da ortodoxia a ser superada (personificada na figura de Christopher Columbus Langdell, o primeiro Dean da Harvard Law School), torna-se bem mais persuasivo o discurso que propunha uma nova compreensão da racionalidade jurídica amparada na substituição de uma lógica de dedução de certezas por uma lógica das consequências. Nas conhecidas palavras de Oliver Wendell Holmes Jr.: "The actual life of the law has not been logic: it has been experience. The felt necessities of the times, the prevalent moral and political theories, intuitions of public policy, avowed or unconscious, even the prejudices which judges share with their fellow-men, have had a good deal more to do than the syllogism in determining the rules by which men should be governed". Cf. Homes Jr. (1887, p. 1). Nesse sentido, cf. também Dewey (1910, p. 26).

12 Apesar das duras objeções recebidas na Alemanha, Kelsen também foi criticado por seus próprios colegas de universidade. Os principais críticos de Kelsen em Viena, Ernst Schwind e Alexander Hold-Ferneck, sustentavam, do ponto de vista metodológico, a necessidade de abertura da ciência do direito para as suas realidades histórica, política e sociológica (para um "plano do ser"), ponto comum em torno do qual também giravam diversas objeções de publicistas alemães. Sobre as críticas desses autores, cf. Korb (2010, capítulo 2, II).

13 Para Jhering (1866, p. 399), o direito é um instrumento de segurança das condições de existência da sociedade.

14 Cf. também Kelsen (1934, p. 32): “O Direito é caracterizado não como fim, mas como um meio específico”.

15 Kelsen (1929, p. 1723): “Como teoria do direito positivo, ela é sobretudo uma teoria geral do direito, que estabelece as ferramentas conceituais por meio das quais se pode apoderar mentalmente de um direito especial”.

16 Neste momento, o principal alvo era a monografia de 1920 intitulada Das Problem der Souveränität und die Theorie des Völkerrechts, na qual Kelsen preconizava a "purificação" do conceito de soberania e já apresentava as bases metodológicas subjacentes à TPD. Purificá-lo significava, para Kelsen, essencialmente libertá-lo de conteúdos políticos e entendê-lo logicamente no âmbito da normatividade de uma ordem jurídica. Cf. Korb (2010, p. 66 s. e 109) e Paulson (2008, p. 9 s.).

17 O longo debate estabelecido entre Kaufmann e Kelsen não se restringe ao texto de 1920 aqui prioritariamente citado. As discussões se desenvolvem na medida em que Kelsen é usado como referência para criticar o próprio positivismo jurídico e o seu projeto metodológico científico de elaboração de teorias sobre o Estado e o Direito. Sobre a campanha antipositivista de Kaufmann e os seus debates com Kelsen, cf. Korb (2010, p. 117 ss.).

18 Essas categorias seriam para Kaufmann (1921, p. 23 ss.) problemáticas porque eram abstratas e vazias no sentido de completamente desvinculadas de organizações sociais reais.

19 Dimitri Dimoulis (2011, p. 217 ss.) caracteriza essa versão do formalismo jurídico como "formalismo metodológico".

20 Na caracterização de Dimoulis (2011, p. 220 ss.), essa versão do formalismo é apresentada como "formalismo estrutural". 
21 Cf. nesse sentido Carl Schmitt (1931, p. 19): “Toda a Justiça está vinculada a normas e cessa quando as próprias normas em seu conteúdo se tornam ambíguas e controversas. Em um Estado como o atual Reich alemão a jurisdição é, por isso, dependente de normas que possibilitam a subsunção adequada aos seus predicados fáticos (tatbestandsmäßige Subsumtion)".

22 Nesse sentido, cf. por exemplo Carl Schmitt (1931, p. 37 s.): “a posição especial do juiz no Estado de Direito [...] reside apenas na noção de que ele decide com base nas leis e de que sua decisão é deduzida materialmente de uma outra decisão, já calculável e mensurável, contida na lei”.

23 O sentido com que Carl Schmitt é apresentado como decisionista pretende destacar o papel da decisão, sobretudo da decisão soberana, como a base da autoridade e o fundamento de validade do direito. Uma perspectiva institucionalista incorporada posteriormente por Schmitt, no entanto, mitiga o decisionismo como elemento central para se entender a soberania. Nas palavras de Ronaldo Porto Macedo Júnior: “A passagem do pensamento do Schmitt de 1922 para o Schmitt de 1933 está justamente no abandono de uma concepção voluntarista stricto sensu de soberania (hobbesiana), na qual a soberania é a decisão do príncipe ou ditador numa situação de caos, para uma concepção ainda hobbesiana, mas agora lato sensu de soberania, na qual a vontade social é expressa por meio de instituições" (1994, p. 201 215 , p. 209). A compreensão adequada do sentido em que Schmitt pode ser considerado um "decisionista" se mostra particularmente relevante neste trabalho na medida em que ele próprio critica o positivismo jurídico (notadamente o positivismo jurídico do século XIX) pelo seu caráter normativista e também decisionista. Assumindo a existência de um compromisso normativo (questionável, diga-se de passagem) do positivismo com a segurança e a calculabilidade incondicional, Schmitt problematiza a visão positivista de acordo com a qual o Judiciário é um "aparelho executor de normas", ao denunciar que, sob a aparente observância das decisões do legislador, os próprios juízes tendem a se colocar acima dessa mesma vontade. Isso acontece quando, sob a chancela de um "Estado de Direito", o jurista exige que as decisões legislativas continuem "em vigência de modo firme e inviolável enquanto norma, isto é, que o próprio legislador estatal também se submeta à lei por ele instituída e à sua interpretação” (cf. Schmitt, 2001, p. 187-188). Assim, afirma Schmitt, "por meio do normativismo da legalidade ele se coloca novamente acima da decisão de poder do Estado, à qual ele se submetera no interesse da segurança e da firmeza, e formula agora pretensões normativas ao legislador. Ele fundamenta, portanto, o seu ponto de vista primeiramente em uma vontade (do legislador ou da lei) e depois, contra a sua vontade, sem mediações de uma lei 'objetiva'” (2001, p. 188). Dessa forma, em nome da segurança por ele aspirada, o jurista positivista também é um decisionista, na medida em que pretende sustentar a força e a validade de suas decisões na autoridade ou soberania do legislador, ainda que, em certos casos, seja a sua própria decisão que pretenda fazer prevalecer. Tal crítica, quando dirigida a Kelsen, parece não atingir o alvo, já que Kelsen, como se aprofundará, também vincula à decisão judicial, por um lado, uma dimensão volitiva, e, por outro, não reconhece compromisso normativo explícito entre direito e, como um objetivo necessário deste, a segurança jurídica.

24 Kelsen (1934, p. 90): “Essa determinação não é, porém, nunca exaustiva”.

25 No caso específico de leituras da obra de um autor que sejam expressamente dissonantes das ideias contidas em seu texto, parece-me possível considerar esse caso de transformação como um verdadeiro erro de compreensão da teoria. Não me parece, por isso, sustentável defender que esses casos de transmutações podem ser considerados valiosos porque as leituras específicas recebidas da obra de um autor em um ambiente de recepção possuem um significado próprio e integram a sua cultura jurídica. A tese geral de López Medina de que as transmutações das ideias provenientes dos locais de produção não podem ser consideradas erros "que requieran de corrección mediante ajustamiento a la lectura estandarizada que se hace en otros sitios" (López Medina, 2004, p. 34) parece-me plausível apenas para possibilidades interpretativas da teoria, e não para as situações, mais uma vez, em que é claro que o autor não defende determinado posicionamento. Correções são necessárias nesses casos não para se criticar o argumento de fundo (por exemplo, se o formalismo é teoricamente defensável ou não, desejável ou não em certo contexto etc.), mas para que sejam desfeitas associações incorretas entre o que o autor efetivamente defende e o que se divulga como o que ele defende, tal qual acontece na afirmação da relação "Kelsen/formalismo qua dedução".

26 Tendências a recepções sincréticas de teorias estrangeiras não são incomuns no Brasil. Como exemplo de sincretismos no âmbito da justaposição de diferentes teorias e técnicas sobre a interpretação constitucional, cf. Silva (2007, p. 115-143).

27 Sobre essa leitura pop da TPD na Colômbia, cf. López Medina (2004, p. 351).

28 No caso de Kelsen, essa perspectiva é explicitamente defendida por Stanley Paulson (2008, p. 39). 
29 Hoerster (1989, p. 10) refere-se a essa tese como “tese da subsunção".

30 É comum encontrar a enunciação da tese da separação nos seguintes termos gerais: não há conexão necessária entre direito e moral. Essa tese, em função da sua amplitude, é considerada como falsa por alguns positivistas, que reconhecem pontos de contato, especialmente no plano metodológico, entre os dois campos. Nos termos apresentados, rejeitam expressamente a tese da separação Jules Coleman (2007, p. 581-608) e Joseph Raz (2007, p. 20 s.).

31 Positivistas inclusivos e exclusivos diferem fundamentalmente em função do modo como interpretam a segunda tese. Enquanto para positivistas exclusivos apenas fatos sociais devem ser responsáveis pela identificação do direito válido, positivistas inclusivos, na conceituação proposta por Coleman, entendem que fatos sociais necessariamente estabelecem o que determina em cada sociedade as condições de validade de normas jurídicas. Nesse sentido, a validade das normas de um sistema jurídico pode contingentemente depender de elementos morais. Acredito que esse último sentido é o mais apropriado para caracterizar Kelsen como um positivista. Cf. Jules Coleman (2009, p. 384 s.).

32 Na definição de Gardner, na qual ambas as teses podem ser identificadas, a designação "positivista" pode ser atribuída apenas a quem endossa a seguinte proposição: "em qualquer sistema jurídico, se uma determinada norma é válida e, portanto, faz parte do direito daquele sistema, é algo que depende das suas fontes, não dos seus méritos (os seus méritos, em sentido relevante, incluem os méritos das suas fontes)” Cf. John Gardner (2001, p. 201).

33 Elas não são, no entanto, as únicas perspectivas metodológicas a partir das quais teorias sobre a natureza do direito são desenvolvidas. Entre outros caminhos possíveis, é factível, por exemplo, também identificar o naturalismo de Leiter (2003, p. 17-51, p. 43 ss.) e o consequencialismo de Schauer (1996, p. 31-56; 2005, p. 493-501). Sobre essas propostas, ver também Dickson (2001, cap. 5).

34 No mesmo sentido, afirma Hart (1998, p. 244) que "description may still be description, even when what is described is an evaluation”.

35 Exemplos de projetos metodológicos normativos sobre a natureza do direito são desenvolvidos por Dworkin (2001, p. 1-37) e Alexy (2008, p. 281-299).

36 Essa crítica sofre de um grave problema conceitual, já que a pressuposta associação necessária entre positivismo jurídico e descritivismo metodológico é falsa. Embora seja verdadeiro que ilustres representantes do positivismo jurídico como Hart e Coleman, além, claro, do próprio Kelsen, sirvam-se dessa abordagem metodológica para executar os seus projetos de investigação da natureza do direito, há positivistas que procuram fundamentar a necessidade de os critérios de identificação do direito não incorporarem elementos morais também sobre bases normativas. Nesses casos, a separação entre direito e moral é defendida não só com base em argumentos conceituais, como também à luz de considerações sobre a efetiva possibilidade de o direito realizar funções relacionadas à sua natureza (como guiar comportamentos ou diluir desacordos morais particulares), visões substantivas sobre algumas das suas propriedades essenciais (notadamente a ideia de autoridade) ou os efeitos positivos (sobretudo epistêmicos) do positivismo jurídico como teoria do direito. Essa associação em alguma medida entre positivismo e normativismo metodológico pode ser encontrada, por exemplo, entre importantes nomes do positivismo exclusivo, como Raz (1996, p. 1-25; 1994, p. 194-221) e Shapiro (2011). Sobre o assunto, cf. também Jeremy Waldron (2001, p. 411-433).

\section{REFERÊNCIAS BIBLIOGRÁFICAS}

ALEXY, Robert. On the concept and the nature of law. Ratio Juris, v. 21, p. 281-299, 2008.

COLEMAN, Jules. Beyond the separability thesis: moral semantics and the methodology of jurisprudence. Oxford Journal of Legal Studies, 27, p. 581-608, 2007.

. Beyond inclusive legal positivism. Ratio Juris, v. 22, 2009.

COMPARATO, Fábio Konder. Ética. Direito, moral e religião no mundo moderno. São Paulo: Companhia das Letras, 2006. DALLARI, Dalmo de Abreu. O poder dos juízes. 2. ed. São Paulo: Saraiva, 2002. 
DEWEY, John. Logic method and law. The Cornell law quartely, v. 10, 1910.

DIAS, Gabriel Nogueira. O positivismo jurídico e a teoria geral do direito na obra de Hans Kelsen. São Paulo: Revista dos Tribunais, 2010.

DICKSON, Julie. Evaluation and legal theory. Oxford: Hart, 2001.

DIMOULIS, Dimitri. Sentidos, vantagens cognitivas e problemas teóricos do formalismo jurídico. In: MACEDO JR., Ronaldo Porto; BARBIERI, Catarina Helena Cortada (Orgs.). Direito e interpretação. Racionalidade e instituições. São Paulo: Saraiva, 2011.

DWORKIN, Ronald. Hart's postscript and the character of political philosophy. Oxford Journal of Legal Studies, v. 24, p. 1-37, 2001.

EBAID, Ana Augusta Rodrigues Westin. O positivismo jurídico de Hans Kelsen e o papel da axiologia jurídica na teoria tridimensional de Miguel Reale. Texto disponível em: <http://intertemas.unitoledo.br/revista/

index.php/ETIC/article/viewFile/1622/1545>. Acesso em: 25 jan. 2013.

GARDNER, John. Legal positivism: 5 1/2 myths. The American Journal of Jurisprudence, v. 46, 2001.

GRAU, Eros Roberto. O direito posto e o direito pressuposto. 11. ed. São Paulo: Malheiros, 2011.

GREY, Thomas. The new formalism. Stanford Law School, Public Law and Legal Series, Working Paper n. 4. Disponível em: <http://ssrn.com/abstract=200732>. Acesso em: 10 jan. 2011.

HART, H. L. A. The concept of law. 2. ed. Oxford: Clarendon Press, 1998.

HELLER, Hermann. Staatslehre. 6. ed. Tübingen: Mohr, 1983. 1992, v. 2.

Die Krisis der Staatslehre. In: MÜLLER, Christoph (Ed.). Gesammelte Schriften. Tübingen: Mohr,

HOERSTER, Norbert. Verteidigung des Rechtspositivismus. Frankfurt a.M.: Metzner, 1989.

HOLMES JR., Oliver Wendell. The common law. London: MacMillan, 1887.

JHERING, R. von. Der Zweck im Recht, I, 5. ed. Leipzig, 1866.

KAUFMANN, Erich. Kritik der neukantischen Rechtsphilosophie: eine Betrachtung über die Beziehungen zwischen

Philosophie und Rechtswissenschaft. Tübingen: Mohr, 1921.

KELSEN, Hans. Juristischer Formalismus und reine Rechtslehre. JuristischeWochenschrift, v. 58, 1929.

Reine Rechtslehre. Leipzig/Viena, 1934.

General theory of law and state. Cambridge: Harvard University Press, 1945.

Wer soll der Hüter der Verfassung sein?. Die Justiz, 1930/31, v. 6.

Reine Rechtslehre. 2. ed. Viena: Österreichische Staatsdruckerei, 1992.

The pure theory of law and analytical jurisprudence. Harvard Law Review, 55 (1941), p. 44-70, reimp.

em BIX, Brian (Ed.). Philosophy of law. Critical concepts in philosophy. London/New York: Routledge: 2006, p. $154-$ 175 , v. II.

KORB, Axel-Johannes. Kelsens Kritiker. Tübingen: Mohr Siebeck, 2010.

LEITER, Brian. Legal realism, hard positivism, and the limits of conceptual analysis. In: COLEMAN, Jules (Ed.). Hart's postscript: essays on the postscript to 'the concept of law'. New York: Oxford University Press, 2001.

. Between the Hart/Dworkin debate: the methodology problem in jurisprudence. The American Journal of Jurisprudence, v. 48, p. 17-51, 2003.

MACEDO JÚNIOR, Ronaldo Porto. O decisionismo jurídico de Carll Schmitt. Lua Nova 32, p. 201-215, 1994.

MEDINA, Diego Eduardo López. Teoría impura del derecho. La transformación de la cultura jurídica latinoamericana.

Bogotá: Legis, 2004.

MÜLLER, Ingo. Hitler's Justice: the courts of the third Reich. Harvard: Harvard University Press, 1992.

OLIVEIRA, Júlio Aguiar de; TRIVISONNO, Alexandre Travessoni Gomes (Orgs.). Hans Kelsen: teoria jurídica e

política. Rio de Janeiro: Forense, 2013.

PAULSON, Stanley. Formalism, 'free law', and the 'cognition' quandary: Hans Kelsen's approaches to legal

interpretation. The University of Queensland Law Journal, v. 27, p. 7-39, 2008.

Zum "Formalismus"-Vorwurf im Weimarer verfassungsrechtlichen Richtungsstreit. In: SIECKMANN,

Jan (Org.). Verfassung und Argumentation. Baden-Baden: Nomos, 2005.

POUND, Roscoe. Law and the science of law in recent theories. Yale Law Journal, v. 43, 1933-4.

RAZ, Joseph. The argument from justice, or how not to reply to legal positivism. In: PAVLAKOS, George (Ed.).

Law, rights and discourse. The legal philosophy of Robert Alexy. Oxford/Portland: Hart, 2007.

On the nature of law. Archiv für Rechts- und Sozialphilosophie, v. 82, p. 1-25, 1996.

Authority, law, and morality. Ethics in the Public Domain, Oxford: OUP, 1994, p. 194-221.

REALE, Miguel. A visão integral do direito em Kelsen. In: PRADO, Luis Regis; KARAM Munir (Coord.). Estudos de filosofia do direito. Uma visão integral da obra de Hans Kelsen. São Paulo: Revista dos Tribunais, 1985.

RODRIGUEZ, Caio Farah. Sentido, valor e aspecto institucional da indeterminação jurídica. Tese (Doutorado em Direito do Estado apresentada à Faculdade de Direito da USP). São Paulo, 2011, Mimeo. 
SARAIVA, Marcos Antonio Maciel. Pós-positivismo, ciências sociais e o papel do magistrado. Disponível em: $<$ http://jus.com.br/revista/texto/21751/pos-positivismo-ciencias-sociais-e-o-papel-domagistrado\#ixzz2J1EP0KAZ>. Acesso 25 jan. 2013.

SCHAUER, Frederick. Formalism. Yale Law Journal, v. 97, p. 509-548, 1988. Positivism as Pariah. In: GEORGE, Robert (Org.). The autonomy of law: essays on legal positivism. Oxford: OUP, p. 31-56, 1996 . . The social construction of the concept of law: a reply to Dickson. Oxford Journal of Legal Studies, v. 25, p. 493-501, 2005

SCHMITT, Carl. Der Hüter der Verfassung. Tübingen: Mohr, 1931. Sobre os três tipos de pensamento jurídico. In: MACEDO JÚNIOR, Ronaldo Porto. Carl Schmitt e a fundamentação do direito. São Paulo: Max Limonad, p. 161-217, 2001.

SCHUARTZ, Luis Fernando. A práxis recalcada na teoria da norma de Kelsen. Norma, contingência e racionalidade. Estudos preparatórios para uma teoria da decisão jurídica. Rio de Janeiro: Renovar, 2005.

SGARBI, Adrian. Teoria pura. In: BARRETO, Vicente (Coord.). Dicionário de filosofia do direito. Rio de Janeiro/São Leopoldo: Renovar/Unisinos, p. 808-813, 2006.

Hans Kelsen (ensaios introdutórios). Rio de Janeiro: Lumen Juris, 2007.

SHAPIRO, Scott J. Legality. Cambridge/London: Belknap, 2011.

SILVA, Virgílio Afonso da. Interpretação constitucional e sincretismo metodológico. In: SILVA, Virgílio Afonso da (Org.). Interpretação constitucional. São Paulo: Malheiros, p. 115-143, 2007.

SMEND, Rudolf. Verfassung und Verfassungsrecht, München: Duncker \& Humblot, 1928.

SUMMERS, Robert. Pragmatischer Instrumentalismus und amerikanische Rechtstheorie: Darstellung und Kritik. Freiburg: Alber, 1983.

SUNSTEIN, Cass. Must Formalism be Defended Empirically? University of Chicago Law Review, v. 66, p. 636-670, 1999. TAMANAHA, Brian, Law as a means to an end: threat to the rule of law. Cambridge: Cambridge University Press, 2006. VERMEULE, Adrian. Judging under Uncertainty. An institutional Theory of Legal Interpretation. Cambridge: Cambridge University Press, 2006.

WALDRON, Jeremy. Normative (or ethical) positivism. In: COLEMAN, Jules (Org.). Hart's Postscript. Essays on the postscript to the concept of law. Oxford: OUP, p. 411-433, 2001.

Fernando Leal 